RESUMO DE DISSERTAÇÃO E TESE

\section{QUALIDADE DE VIDA E INSÔNIA NA PERIMENOPAUSA: MEDITAÇÃO COMO ESTRATÉGIA DE INTERVENÇÃO}

\section{QUALITY OF LIFE AND INSOMNIA IN PERIMENOPAUSAL MEDITATION AS AN INTERVENTION STRATEGY}

\section{RESUMO}

Introdução: A insônia está entre os mais frequentes transtornos que afetam a população na contemporaneidade, devido a mudanças hormonais e psicossociais importantes é muito prevalente na perimenopausa. Há uma relação ainda pouco estudada entre eficiência do sono e prática meditativa. Os tratamentos utilizados para insônia normalmente são de alto custo e paliativos. Objetivo: Avaliar o efeito da meditação na insônia (causada por sintomas característicos da perimenopausa) e qualidade de vida nesta fase da vida. Método: Ensaio clínico controlado para avaliar os efeitos da meditação em mulheres com insônia no período da perimenopausa e o impacto na qualidade de vida em 8 semanas de intervenção. $O$ estudo foi realizado de abril a julho de 2013 com 33 mulheres na perimenopausa de idade entre 40 a 55 anos em 3 unidades de órgão público no município de São Paulo, SP. As participantes foram divididas aleatoriamente em dois grupos, um que praticou somente Higiene do Sono-HS ( $\mathrm{n}=15)$ e outro que praticou Meditação + Higiene do Sono-M+HS (n=18). Foram realizados encontros semanais com as participantes de ambos os grupos para pratica de meditação em grupo e/ou critérios de higiene do sono. $\mathrm{O}$ grupo $\mathrm{M}+\mathrm{HS}$ também realizou prática diária de meditação. Para avaliar a significância estatística das diferenças de médias antes e depois das intervenções em cada grupo foi utilizado o teste de Wilcoxon. Resultados: Houve melhora da insônia em ambos os grupos, no entanto comparando as diferenças de escore do Índice de Gravidade de Insônia entre os grupos estudados, o grupo M+HS teve um efeito superior em ambas as medições em relação ao grupos

\author{
Caio Fábio Schlechta Portella \\ - Programa de Pós Graduação em \\ Saúde Pública - Faculdade de Saúde \\ Pública da Universidade de São Paulo \\ - Área de Concentração: Saúde \\ Ciclos de Vida e Sociedade \\ - Orientadora: Profa Dra Ana Cristina \\ d'Andretta Tanaka (acdatana@usp.br) \\ - Data da Defesa: 25/03/2014
}


HS. No grupo M+HS, houve redução estatisticamente significativa nas categorias do Índice Menopausal de Kupperman: Palpitação, Parestesia e a Pontuação Total já no grupo HS não houve redução significativa em nenhum parâmetro do Índice de Kupperman. Houve melhora significativa da pontuação geral de qualidade de vida aferida pelo WHOQOL breve no grupo $\mathrm{M}+\mathrm{HS}$, e no grupo HS houve melhora no domínio relações sociais. Conclusão: Os resultados sugerem que a meditação pode ser ferramenta útil no tratamento da insônia primária durante o período da perimenopausa. A qualidade de vida durante este período também é favorecida de maneira global pela prática diária de meditação.

\title{
PALAVRAS-CHAVE
}

Insônia.

Meditação.

Perimenopausa.

Climatério.

Insônia Primária.

Qualidade de Vida.

Naturologia.

\begin{abstract}
Introduction: Insomnia is one of the most common disorders that affect the population in contemporaneity, because of important hormonal and psychosocial changes is very prevalent in perimenopause. There is a still understudied relationship between sleep efficiency and meditative practice. The treatments for insomnia are usually expensive and palliative. Objective: Evaluate the effects of meditation in insomnia (caused by typical symptoms of perimenopause) and quality of life in this phase of life. Method: controlled clinical trial to evaluate the effects of meditation in women with insomnia during perimenopause and impact on quality of life in 8-week intervention. The study was conducted from April to July 2013 with 33 perimenopausal women aged between 40-55 years in 3 units of public organization in São Paulo, SP, Brazil. The participants were randomly assigned to two groups, one who performed only Sleep Hygiene-HS ( $\mathrm{n}=15)$ and another who performed Meditation + Sleep Hygiene $-\mathrm{SH}+\mathrm{M}(\mathrm{n}=18)$. Weekly meetings were held with the participants of both groups to practice meditation in a group and / or criteria for the sleep hygiene. The $\mathrm{M}+\mathrm{SH}$ group also performed daily meditation practice. To assess the statistical significance of differences in means before and after the interventions in each group, the Wilcoxon test was applied. Results: Improvement of sleep quality in both groups, however comparing the differences in the scores of the Insomnia Severity Index between groups, group $\mathrm{M}+$ $\mathrm{SH}$ had a greater effect on both measures compared to the SH group. In $\mathrm{M}+\mathrm{SH}$ group showed a statistically significant reduction in the categories of the Kupperman Menopausal Index: palpitations, paresthesia and Total Score, already in the SH group there was no significant reduction in any parameter of the Kupperman Index. A Significant improvement in overall quality of life (measured by WHOQOL-brief) score in group M + HS, and HS group had improvement in social relationships domain. Conclusion: The results suggest that meditation can be useful tool in the treatment of primary insomnia during the perimenopause. The quality of life during this period is also favored globally by daily meditation practice.
\end{abstract}

KEYWORDS: Insomnia. Meditation. Perimenopause. Climacterium. Primary insomnia. Quality of life. Naturology. Naturopathy. 